\title{
Prediction and Control Model of Musculoskeletal Disorders in the Instant Noodle Company in Makassar 2020-2050
}

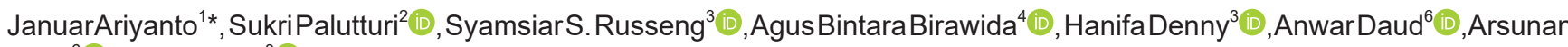 \\ $\operatorname{Arsin}^{6} \mathbb{D}$, Atjo Wahyu $^{3}$ D \\ ${ }^{1}$ Public Health Doctoral Program, Faculty of Public Health, Universitas Hasanuddin, Makassar, Indonesia; ${ }^{2}$ Department of Health \\ Administration and Policy, Universitas Hasanuddin, Makassar, Indonesia; ${ }^{3}$ Department of Occupational Health and Safety, \\ Universitas Hasanuddin, Makassar, Indonesia; ${ }^{4}$ Department of Environmental Health, Faculty of Public Health, Universitas \\ Hasanuddin, Makassar, Indonesia; ${ }^{5}$ Department of Occupational Safety and Health, Faculty of Public Health, Universitas \\ Diponegoro, Semarang, Indonesia; ${ }^{6}$ Department of Epidemiology, Universitas Hasanuddin, Makassar, Indonesia
}

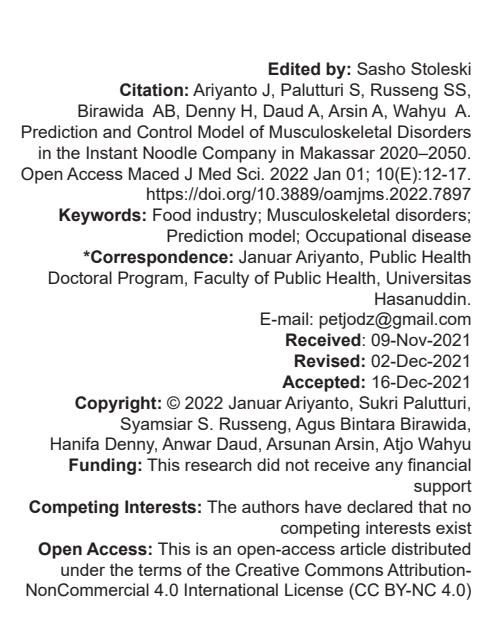

Introduction

Changes in consumption patterns that occurred during the Corona Virus 2019 pandemic caused an increase in demand for instant food availability, which results in the emergence of consumer stockpiling and panic buying [1], [2]. As a result, demand for food production continues to increase [3], even though the prices have increased by $8-25 \%$ compared to the pre-pandemic conditions [4]. In addition, it causes an increase in production capacity in the food processing industry due to the high market demand, which impacts the lack of mobility possessed by the community during the pandemic [5].

Musculoskeletal disorders are still a problem for workers with physical activity demands such as lifting, pulling, pushing, standing, walking, bending, and also repetitive work. The pain caused makes it difficult for workers to carry out the work activities. Furthermore, the impact on workers due to MSDs can also in the forms of a lack of productivity, sick leave and at worst stopping work [6], [7], [8], [9].

Due to the high market demand that must be met, workers receive adverse health consequences in work-related injuries and reported occupational diseases [6]. Based on the report on the number of occupational accidents and diseases cases in the past 9 years (2011-2019), there were 791,807 incidents in the industrial sector and resulted in a total of $86,316,874.45$ days lost due to the occupational accidents and diseases [7], [8]. One of the particular concerns related to occupational diseases in the food processing industry is musculoskeletal disorders [9]. The 
Table 1: Risk variables for the musculoskeletal disorders incidence before and after treatment

\begin{tabular}{lll}
\hline Variable & Before treatment & After treatment \\
\hline Lifting load & $10 \mathrm{~kg}$ & $7 \mathrm{~kg}$ \\
Working posture & REBA score $=8$ & REBA score $=3$ \\
Working duration & $8 \mathrm{~h} /$ day & $7 \mathrm{~h} /$ day \\
\hline
\end{tabular}

food processing industry is still handling loads manually or conduct high-frequency manual handling [10]. Therefore, to obtain maximum work productivity in the industrial sector, it requires intense manual labor and psychological pressure [11].

The occurrence of musculoskeletal disorders in a past process to produce a product depends on the production process and the risk factors in the work environment [12], [13]. Several risk factors cause musculoskeletal disorders in the workers, including repetitive tasks, awkward/stressed postures, and manual material handling [14], [15], [16]. These risk factors are certainly exacerbated by the working hours of each worker and management policies regarding overtime [17].

In the instant food industry, apart from manual load handling and repetitive work, there are also other risks that come from the production process. The operation of machines that are not in accordance with anthropometry [18], [19] and vibrations [20], [21] caused by machines are risk factors that trigger the musculoskeletal disorders among workers. Therefore, special attention is needed on the ongoing production process to control the musculoskeletal disorders incidence.

As previously mentioned, many risk factors result in musculoskeletal disorders in the industrial sector. Therefore, this study used interpretative structural modeling (ISM) to determine variables that can be controlled to suppress the musculoskeletal disorders incidence in the next 50 years [22],[23], [24]. The advantage of interpretive structural modeling compared to other methods is on its ability to determine the key elements at the root of the problem discussed based on the priority of elements or variables that are directly related to an incident [25], [26]. Based on these considerations, we considered that ISM is a relevant and applicable method to determine the key elements in the musculoskeletal disorders incidence in the instant food industry. Meanwhile, valuable information for controlling and preventing occupational diseases was obtained from predictions of research models [27].

The control of musculoskeletal disorders incidence in this study was done by carrying out treatment scenarios on variables that are key elements through a dynamic system approach using software. The scenario that was carried out on the model aimed to find out the phenomena contained in a dynamic system based on mathematical calculations [28]. The advantage of using a dynamic systems approach to research is that it provides predictions (a foresight) that other methods cannot and are more efficient than trial and error methods; where the scenario simulation process uses software [29], [30].

Based on the points above, this study aims to answer several research questions. Those research questions include the key elements in controlling musculoskeletal disorders, predictions of musculoskeletal disorders in the next 50 years, and the effectiveness of scenario developed in controlling musculoskeletal disorders on workers of the production section of an instant noodle company in Makassar.

\section{Methods}

The sample of this study was divided into two, for quantitative analysis using aggregate data on the incidence of musculoskeletal disorders recorded at company occupational health and safety facilities in 2017-2020, and for qualitative data obtained based on the results of interviews with academics, policy makers and practitioners in the field of safety and health. Totaling 23 respondents. Furthermore, the results of the interviews were processed using ISM to draw conclusions about the key variables in controlling the incidence of musculoskeletal disorders.

This research was conducted in one of the industries that produce instant noodle in South Sulawesi, Indonesia. The selection of this location was based on an initial study at the research location which stated that there were many cases of musculoskeletal disorders that were recorded in the health and safety reports of occupational health and safety facilities. This study uses the Research and Development method through a dynamics system approach [31].

Dynamic modeling begins by making a flow diagram of the estimation model for the incidence of musculoskeletal disorders in the instant food industry. To get the right policy scenario in reducing the incidence of musculoskeletal disorders, ISM is used. In applying the ISM model, interviews with stakeholders from academics and practitioners were conducted to gather ideas for controlling the incidence of musculoskeletal disorders in the instant food industry. The data obtained based on interviews, and then analyzed using ISM. The results of the ISM analysis were implemented on the model treatment using Powersim Studio 10 Express. Powersim Studio 10 Express is one of the software made by Powersim Software which is domiciled in Norway. 


\section{Results}

\section{Evaluation of ISM}

ISM method was used to analyze the interrelationships and dependencies between the elements that make up the structure of the musculoskeletal disorders control model at an instant noodle company in Makassar. Based on the results of discussions with experts and expert judgment and the analysis results of nine constraint elements on the musculoskeletal disorders incidence, it shows that the key elements in controlling musculoskeletal disorders at the instant noodle company in Makassar are work posture, lifting load, and length of work.

Based on the value of Driver Power and Dependence in Figure 1 above, the 9 constraint elements are categorized into four sectors, those are: Autonomous factors, dependent factors, linkage factors, and Independent factors. Furthermore, based on the analysis results, it shows that work posture, lifting weight and length of work are included in Independent factors, in which the elements that enter this sector are elements that have strong driving power and weak dependence. Elements in this sector are elements that are key factors in model building.

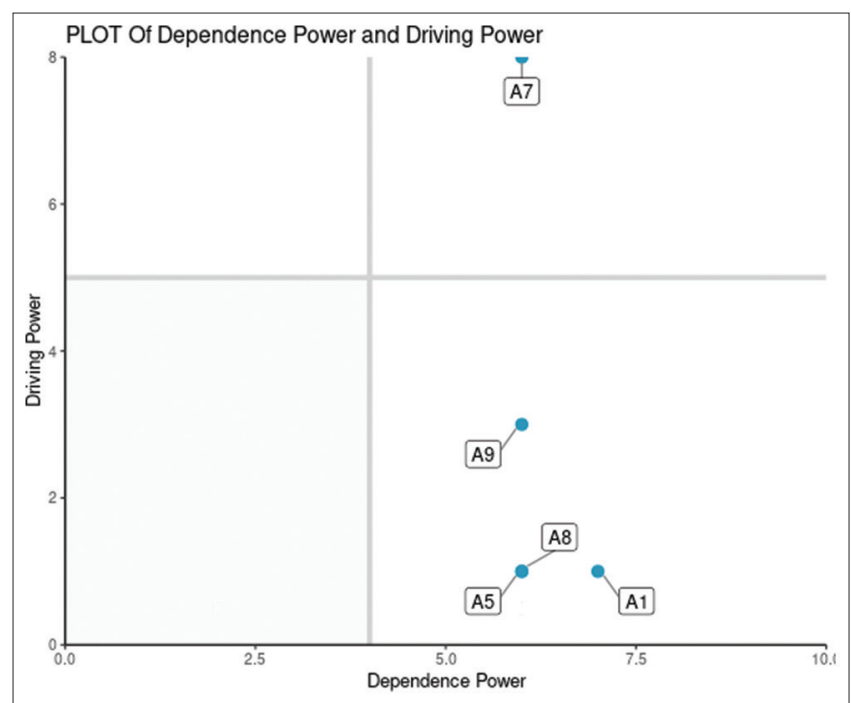

Figure 1: Matrix driver power $(D p)$ and dependence $(D)$ for constraint elements in musculoskeletal control model disorders in instant Noodle Company in Makassar

Based on Figure 2, the analysis of 9 sub-elements of musculoskeletal disorders based on interviews with occupational health and safety experts, company management, and stakeholders shows that the sub-elements that have a considerable driving force in the prevention program for musculoskeletal disorders in the instant food industry are work posture, lifting load and working duration.

As seen on Figure 3 , the following is a dynamic model of controlling the musculoskeletal disorders incidence, which was built based on the field conditions and the factors that cause musculoskeletal disorders in the instant noodle industry in Makassar.

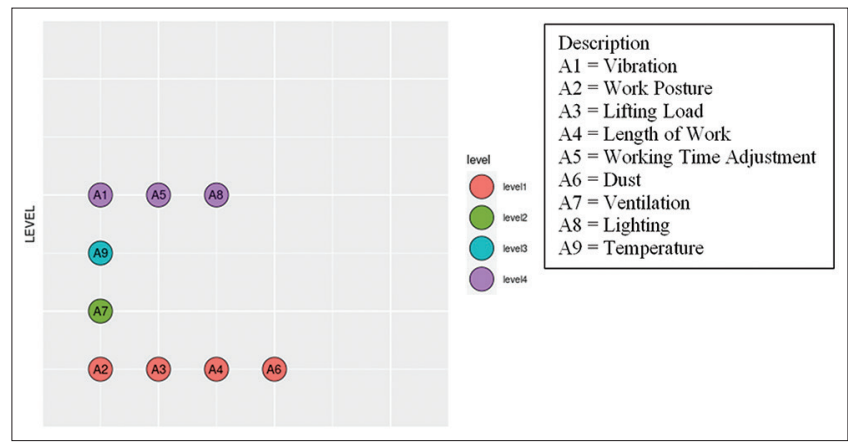

Figure 2: Hierarchical diagram of the constraint elements in the development of a model for controlling the musculoskeletal disorders incidence in the food industry

Based on Table 1, it is known that the results of field measurements based on secondary data taken in the vulnerable years during the research show the average results of the variables that affect the incidence of musculoskeletal disorders. Then treatment is carried out on these variables using a dynamic system approach following applicable regulations regarding the threshold value adjusted to the conditions in the field when the research takes place.

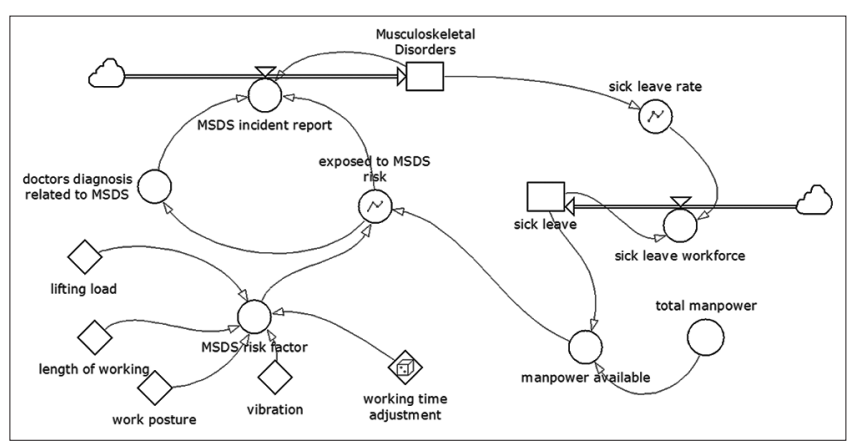

Figure 3: Model of musculoskeletal disorders incidence in instant Noodle companies in Makassar

Based on the simulation results for 30 years (Figure 4), it was found that there was an increase in the average incidence of musculoskeletal orders of $20.63 \%$ per year. At the beginning of the 2020 simulation, the number of musculoskeletal events ordered was

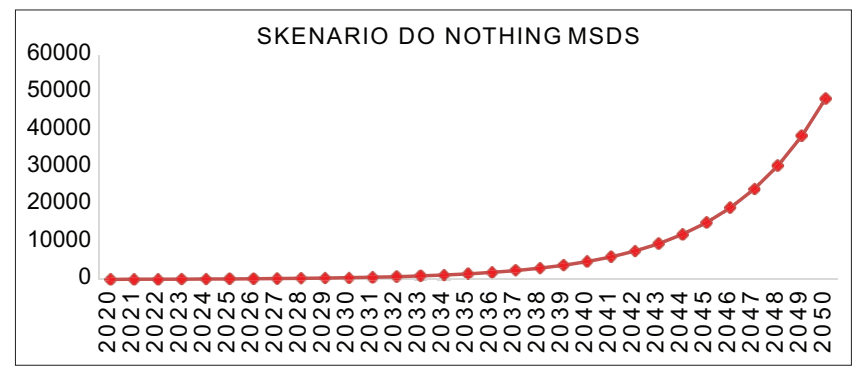

Figure 4: Result of predictions for 30 years from 2020 to 2050 on the occurrence of musculoskeletal disorders at instant noodle companies in Makassar

47.25, which increased continuously. At the end of the simulation, in 2050, the number of musculoskeletal 
events ordered became 48481.69 events. This happens because the number of markets demands that must be met every year continues to increase until the end of the simulation in 2050.

As is known on Figure 5 that from the simulation results for 30 years (2020-2050), musculoskeletal disorders have the most significant contribution to the increase in the number of occurrences of occupational diseases as a whole. The increase in musculoskeletal disorders is an accumulation of several risk factors that exist in the instant noodle production process.

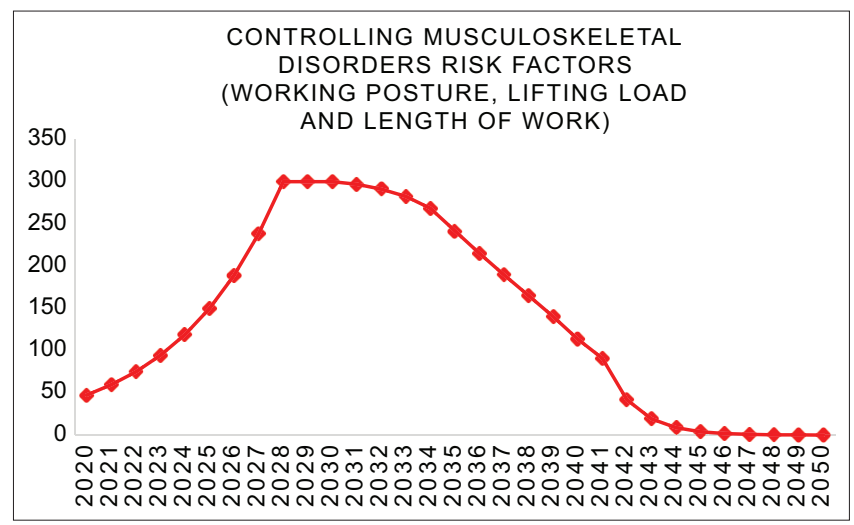

Figure 5: Simulation for 30 years (2020-2050) on a model of controlling occupational diseases at an instant noodle company in Makassar by providing treatment in the form of reducing risk factors that cause musculoskeletal disorders

The data from the analysis of body posture at work obtained a value of 8 which means that the posture when working in the workforce is in a high-risk condition, and changes in work posture must be carried out immediately. Furthermore, it is known that to carry out the production process, the workforce has a lifting load of $10 \mathrm{~kg}$. Based on Regulation of Minister No. 5 of 2018, the threshold value for lifting goods with an extended distance (>60 cm horizontal distance) is $7 \mathrm{~kg}$.

Based on the data obtained above and the results of expert interviews using ISM, it can be concluded that to control the musculoskeletal disorder incidence, the elements or variables controlled simultaneously are work posture, lifting load and length of work.

\section{Discussion}

One technique that can be used to formulate the role of occupational disease control programs is "Interpretative Structural Modeling," which is a method of making decisions from complex situations by connecting and organizing ideas in visual maps. ISM is modeling that describes the specific relationship between variables, the overall structure and has an output in the form of a graphical model in quadrants and variable levels [32]. It is known that in the hierarchical diagram of the constraint elements in the development of an occupational disease control model for instant noodle companies in Makassar, the elements that become level I are Work Posture (A2), Lifting Load (A3), Working Duration (A4), and Dust (A6). This means that the elements have a strong driving force. This analysis explains that ISM does not attempt to break down a problem or situation into smaller parts but rather connecting the ideas in building a situation model. Because of these peculiar properties, ISM excels at solving high-level problems, vis-a-vis cause-root analysis, complex process definitions, or simply a concept. A simple application of ISM, including grouping and sequencing, is used in industrial activities [27].

The determination of critical elements in the occupational disease control model built in this study was based on the type of occupational disease that occurs in instant noodle companies. This was done because of the hierarchical diagram of the constraint elements, which are the results of the ISM analysis in which there are several variables at the level I. This is in line with Awuzie's research in 2019 that interpretive structural modeling (ISM) showed a paired relationship between categories of organizational factors identified in a system [33]. This is also in line with research conducted by Careza in 2020, where the determination of risk factors for an occupational disease must involve the working duration, which is a factor that has a significant influence on the quality of life of workers and complaints on health [34].

The increase of the musculoskeletal disorder incidence in simulations without scenarios for 30 years is controlled in the scenario, where the control scenario is carried out in 2027. Based on the simulation scenarios results, there was a decrease of musculoskeletal disorder incidence that affects the total amount of occupational diseases at the instant noodle company. The decrease in the number of occupational diseases due to the treatment of work posture variables, lifting loads and length of work is in line with research conducted by Hwang in 2011 that the effect of lifting angles, lifting loads and work duration has an impact on the incidence of workers' muscle injuries [35]. The same thing was expressed in research conducted on catering industry workers that risk factors that cause musculoskeletal disorders are long work duration, repetitive work postures, non-ergonomic equipment, and limited workplaces [31].

In this study, control was carried out using a dynamic system approach. The dynamic systems approach is referred to the mathematical formulation of the physical/chemical/biological processes found in the workplace, work processes and production processes to produce instant noodles. Therefore, if supporting data are input, then calculation was done using certain calculation methods, it will be able to an overall picture of the process is generated. All production processes contained in the instant noodle company are 
conceptualized into a dynamic system. A model was formulated to be simulated for the next 30 years from 2020 to 2050. Furthermore, the control was carried out to make changes to the values contained in the constants contained in the occupational disease control model. The impact of changes from a dynamic system is a causal relationship that affects each other [36].

The work environment is an activity of identifying and evaluating environmental factors that affect the health of the workers. Meanwhile, the supervision of the work environment is a series of supervisory activities of all actions taken by worker inspectors for the fulfillment of the implementation of laws and regulations on the object of supervision of the work environment. A clean and healthy work environment is a practice that can minimize the appearance of PAK and provides a work atmosphere that encourages workers to give their best [37].

Frank $E$ Bird mentions a modification of the domino theory that occupational accidents and diseases are not caused by one factor alone, but rather a multifactor interaction that reflects the management [38]). The first thing is the weakness of management control (lack of control). Control is one of the four functions of management. This function relates to managers in all administration, marketing, quality control, engineering, ordering, and safety. In addition to the causal factors mentioned, there are other several variables that we did not include in the assessment of the musculoskeletal disorders incidence in the workers such as smoking habits, exercise habits, lifestyle, and several other variables which are not directly related to work but cause musculoskeletal disorders.

\section{Conclusions}

The critical elements in the control model of musculoskeletal disorders at an instant noodle company in Makassar based on the interpretation of ISM are work posture, lifting load, and working duration. Four control scenarios were carried out using a dynamic system approach in the model of controlling the occupational disease incidence at an instant noodle company in Makassar. These scenarios include Do Nothing Scenario, Musculoskeletal Disorder Scenario (work posture, lifting load, and working duration). The prediction of the musculoskeletal disorder incidence using a dynamic system approach for 30 years (2020-2050) has increased by an average of $20.63 \%$ per year. The behavior of the model after receiving treatment on the musculoskeletal disorder incidence has an average decrease of $51.11 \%$ per year.

The impact of this research is the decrease in the musculoskeletal disorder incidence in predictions from 2020 to 2050 as a result of treatment on work posture, lifting load, and working duration variables through a dynamic system approach using Powersim software. The determination of the controlled variables in this study used the conclusions of expert interviews through interpretive structural modeling.

\section{References}

1. Hao N, Wang $\mathrm{HH}$, Zhou $\mathrm{Q}$. The impact of online grocery shopping on stockpile behavior in Covid-19. China Agric Econ Rev. 2020;12(3):459-70.

2. Wang $\mathrm{HH}$, Chen J, Bai J, Lai J. Meat packaging, preservation, and marketing implications: Consumer preferences in an emerging economy. Meat Sci. 2020;145:300-7. https://doi. org/10.1016/j.meatsci.2018.06.022 PMid:30007176

3. Heck S, Campos H, Barker I, Okello JJ, Baral A, Boy E, et al. Resilient agri-food systems for nutrition amidst COVID-19: Evidence and lessons from food-based approaches to overcome micronutrient deficiency and rebuild livelihoods after crises. Food Secur. 2020;12(4):823-30.

4. Torero M. Without food, there can be no exit from the pandemic. Nature. 2020;580(7805):588-9. https://doi.org/10.1038/ d41586-020-01181-3

PMid:32327745

5. Xiong C, Hu S, Yang M, Younes HN, Luo W, Ghader S, et al Data-Driven Modeling Reveals the Impact of Stay-at-home Orders on Human Mobility during the COVID-19 Pandemic in the U.S. arxiv. 2020;2020:00667.

6. Andersen L, Mortensen O, Hansen JV. A prospective cohort study on severe pain as a risk factor for long-term sickness absence in blue-and white-collar workers. Occup Environ Med. 2011;68(8):590-2. https://doi.org/10.1136/oem.2010.056259 PMid:21071754

7. Punnett L, Wegman DH. Work-related musculoskeletal disorders: The epidemiologic evidence and the debate. J Electromyogr Kinesiol. 2004;14(1):13-23. https://doi. org/10.1016/j.jelekin.2003.09.015 PMid:14759746

8. Neupane S, Virtanen P, Leino-Arjas P, Miranda H, Siukola A Nygård $\mathrm{CH}$. Multi-site pain and working conditions as predictors of work ability in a 4-year follow-up among food industry employees. Eur J Pain (United Kingdom). 2013;17(3):444-51. https://doi.org/10.1002/j.1532-2149.2012.00198.x PMid:22865480

9. Natvig B, Eriksen W, Bruusgaard D. Low back pain as a predictor of long-term work disability. Scand J Public Health. 2002;30(4):288-92.https://doi.org/10.1080/14034940210133951 PMid:12680505

10. Qi $\mathrm{Y}$, Liang $\mathrm{T}, \mathrm{Ye} \mathrm{H}$. Occupational status, working conditions, and health: Evidence from the 2012 China labor force dynamics survey. J Chinese Sociol. 2020;7(1):1-23

11. International Labour Organization. Days Lost Due to Cases of Occupational Injury with Temporary Incapacity for Work by Economic Activity. Ganeva: International Labour Organization.; 2020.

12. International Labor Organization. Cases of fatal occupational injury by economic activity. Ganeva: International Labor Organization; 2020.

13. Ariyanto J, Palutturi S, Russeng SS, Birawida A, Warsinggin W, Rosyanti L. Control of the risk of musculoskeletal disorders in 
the food industry: Systematic review. Ann Rom Soc Cell Biol. 2021;25(1):4254-61.

14. Botti L, Mora C, Regattieri A. Improving ergonomics in the meat industry: A case study of an Italian ham processing company. IFAC-PapersOnLine. 2015;48(3):598-603. https://doi. org/10.1016/j.ifacol.2015.06.147

15. de M Guimarães LB, Ribeiro JL, Renner JS, De Oliveira PA. Worker evaluation of a macroergonomic intervention in a Brazilian footwear company. Appl Ergon. 2014;45(4):923-35. https://doi.org/10.1016/j.apergo.2013.11.007 PMid:24461952

16. Yahya NM, Zahid MN. Work-related musculoskeletal disorders (WMDs) risk assessment at core assembly production of electronic components manufacturing company. IOP Conf Ser Mater Sci Eng 2018;319:012036.

17. Bao S, Howard N, Lin JH. Are work-related musculoskeletal disorders claims related to risk factors in workplaces of the manufacturing industry? Ann Work Expo Health. 2020;64(2):152-64. https://doi.org/10.1093/annweh/wxz084 PMid:31785202

18. Yang ST, Park MH, Jeong BY. Types of manual materials handling $(\mathrm{MMH})$ and occupational incidents and musculoskeletal disorders (MSDs) in motor vehicle parts manufacturing (MVPM) industry. Int J Ind Ergon. 2020;77:102954.

19. Kanniappan V, Palani V. Prevalence of musculoskeletal disorders among sewing machine workers in a leather industry. J Lifestyle Med. 2020;10(2):121-5. https://doi.org/10.15280/ jlm.2020.10.2.121 PMid:32995340

20. Kee D. Comparison of OWAS, RULA and REBA for assessing potential work-related musculoskeletal disorders. Int J Ind Ergon. 2021;83:103140.

21. Kuta $Ł$, Szyjewicz D, Patrzalek W, Gorecki K, Rybka I. Assessment of exposure to disorders among building industry workers performing selected tasks. J Hum Resour Manag Res. 2021;2021:921309. https://doi.org/10.5171/2021.921309

22. Ferdyastari N, Adiatmika IPG, Purnawati S. Workstation Improvement Dan Pemberian Stretching Karyawan Pembersihan Injeksi Menurunkan Kebosanan Kerja, Keluhan Muskuloskeletal, Dan Meningkatkan Produktivitas Pada Industri Perak Di Cv Jps. J Ergon Indones. 2018;4(1):3. https://doi. org/10.24843/JEl.2018.v04.i01.p03

23. Nallusamy S, Shah P, Singh SK, Pilla N, Hamid Reza MD. Evaluation of human posture and ergonomics by appropriate assessment tool in a medium scale manufacturing industry. Int J Mech Prod Eng Res Dev. 2020;10(3):861-72.

24. Gauthier F, Gélinas D, Marcotte P. Vibration of portable orbital sanders and its impact on the development of work-related musculoskeletal disorders in the furniture industry. Comput Ind Eng. 2012;62(3):762-9.

25. Vihlborg P, Bryngelsson IL, Lindgren B, Gunnarsson LG, Graff P. Association between vibration exposure and hand-arm vibration symptoms in a Swedish mechanical industry. Int $\mathrm{J}$ Ind Ergon.

\section{7;62:77-81.}

26. Abellana DP. An interpretative structural modelling approach to analysing root causes of defective jobs: A case study in an automobile service industry. Int J Product Qual Manag. 2020;31(1):1-27. https://doi.org/10.1504/IJPQM.2020.109327

27. Lu Y, Yan H, Zhang L, Liu J. A comparative study on the prediction of occupational diseases in china with hybrid algorithm combing models. Comput Math Methods Med. 2019;2019:8159506. https://doi.org/10.1155/2019/8159506

28. Awan U, Kraslawski A, Huiskonen J. Understanding influential factors on implementing social sustainability practices in Manufacturing Firms: An interpretive structural modelling (ISM) analysis. Proc Manufact. 2018;17:1039-48. https://doi. org/10.1016/j.promfg.2018.10.082

29. Liu P, Li Q, Bian J, Song L, Xiahou X. Using interpretative structural modeling to identify critical success factors for safety management in subway construction: A China study. Int J Environ Res Public Health. 2018;15(7):1359. https://doi.org/10.3390/ijerph15071359 PMid:29958438

30. Roy Ghatak R. Barriers analysis for customer resource contribution in value co-creation for service industry using interpretive structural modeling. J Model Manag. 2020;15(3):1137-66. https://doi.org/10.1108/JM2-07-2019-0168

31. Yang Z, Guo X, Sun J, Zhang Y. Contextual and organizationa factors in sustainable supply chain decision making: Grey relational analysis and interpretative structural modeling. Environ Dev Sustain. 2021;23:12056-76.

32. Matthies M, Malchow H, Kriz J. Integrative Systems Approaches to Natural and Social Dynamics: Systems Science 2000. Germany: Springer-Verlag Berlin Heidelberg; 2001.

33. Jayadinata AK. Ragam Model Pembelajaran di Sekolah Dasar. Sumedang: UPI Sumedang Press; 2012.

34. Ndii MZ. Permodelan Matematika Dinamika Populasi dan Penyebaran Penyakit Akibat; Teori, Aplikasi dan Numerik. Edisi Pert. Yogyakarta: Deepublish (Grup Penerbitan CV Budi Utama); 2018. p. 140.

35. Sugiyono S. Metode Penelitian Kuantitatif, Kualitatif, dan R and D. Bandung: CV Alfabeeta; 2017.

36. Jin X. Porcine-Stimulated Human Tr1 Cells Showed EnhancedSuppression in Xenoantigen Stimulation Response. Vol. 36. United States: Wolters Kluwer Health, Inc.; 2018. p. 108-9.

37. Darmawan DP. Pengambilan Keputusan Terstruktur Dengan Interpretative Structural Modeling. $1^{\text {st }}$ ed. Yogyakarta: Penerbit ELMATERA; 2017.

38. Awuzie BO, Abuzeinab A. Modelling organisational factors influencing sustainable development implementation performance in higher education institutions: An interpretative structural modelling (ISM) approach. Sustain. 2019;11(16):4312. https://doi.org/10.3390/su11164312 